\title{
Altered Expression of the ERM Proteins in Lung Adenocarcinoma
}

\author{
Masahide Tokunou, Toshiro Niki, Yukihito Saitoh, Hiroji Imamura, \\ Michiie Sakamoto, and Setsuo Hirohashi
}

Pathology Division (MT, TN, MS, SH), National Cancer Center Research Institute, Tokyo, and Department of Thoracic and Cardiovascular Surgery (MT, YS, HI), Kansai Medical University, Osaka, Japan

SUMMARY: Radixin is a member of the ERM (ezrin/radixin/moesin) protein family that is proposed to function as a membrane-cytoskeletal linker. Using differential display analysis, we have identified radixin as a gene down-regulated in primary lung adenocarcinoma. Real-time quantitative reverse transcription polymerase chain reaction confirmed that radixin mRNA was decreased, both in 10 early-stage bronchioloalveolar carcinomas and in 16 invasive lung adenocarcinomas, by $69 \%(p=0.0002)$ and $82 \%(p<0.0001)$, respectively, compared with 9 nontumor lung tissues. Similarly, moesin and ezrin mRNA levels were reduced in lung adenocarcinoma. Immunohistochemistry confirmed that cancer cells expressed very little radixin and moesin, whereas non-neoplastic alveolar and bronchiolar epithelial cells, and endothelial cells, including those within the tumor stroma, were consistently positive for these two proteins. Ezrin was localized in the apical surface of non-neoplastic bronchiolar and alveolar epithelial cells and, in contrast to radixin and moesin, the majority of tumor cells retained expression of ezrin. Localization of ezrin was altered in a significant proportion of tumor cells: whereas tumor cells forming lumina displayed membranous staining on the apical side, tumor cells with disorganized structures were either negative or diffusely positive for ezrin in the cytoplasm. Furthermore, a fraction of tumor cells invading the stroma in a scattered manner were strongly positive for ezrin. In conclusion, expression of radixin and moesin is down-regulated in lung adenocarcinoma, including early-stage bronchioloalveolar carcinoma. An intriguing implication of this finding is that these two genes may function as tumor suppressors in lung adenocarcinoma oncogenesis. Although structurally related to radixin and moesin, ezrin may have a distinct function in tumor-cell invasion. (Lab Invest 2000, 80:1643-1650).

$O$ $f$ the various malignant tumors, lung cancer is the most common cause of cancer death worldwide. However the biological behavior of lung cancer is not fully characterized, and the outcome of surgical treatment remains unsatisfactory. Identification of genes that are involved in tumorigenesis and in the progression of lung cancer will be required to formulate more effective therapies. One approach to the identification of such genes is to use differential display analysis (Bauer et al, 1993; Liang and Pardee, 1992; Liang et al, 1992, 1993; Sager et al, 1993; Yoshikawa et al, 1998).

Radixin is a member of the ERM (ezrin/radixin/ moesin) family of proteins (Mangeat et al, 1999; Sato et al, 1992), which was first isolated as a constituent of adherence junctions in rat liver (Tsukita and Hieda, 1989). Ezrin was first purified as a component of intestinal microvilli that is tyrosine-phosphorylated by epidermal growth factor receptor (EGFR; Bretscher, 1989), and moesin was originally identified as a

Received May 25, 2000

This work was supported by a Grant-in-Aid for the Research on Human Genome and Gene Therapy and a Grant-in-Aid for the Second Term Comprehensive 10-Year Strategy for Cancer Control from the Ministry of Health and Welfare of Japan.

Address reprint requests to: Dr. H. Hirohashi, Pathology Division, National Cancer Center Research Institute, 5-1-1 Tsukiji, Chuo-ku, Tokyo, 104-0045, Japan. Fax: 81-3-3248-2463; E-mail: shirohas@gan2. ncc.go.jp heparin-binding protein (Lankes and Furthmayr, 1991). The amino-terminal half of the ERM protein is about $85 \%$ homologous, whereas homology in the carboxy-terminal half is about $65 \%$ (Mangeat et al, 1999). The ERM proteins bind to actin filaments at their carboxy-terminal domain (Algrain et al, 1993; Henry et al, 1995; Turunen et al, 1994), and to several integral membrane proteins, such as CD43, CD44, and ICAM-1, -2, and -3 , and so on, at their aminoterminal domains (Heiska et al, 1998; Mangeat et al, 1999; Yonemura et al, 1998). The ERM proteins are involved in a variety of cellular functions, such as cell adhesion, migration, and the organization of cell surface structures (Bretscher et al, 1997; Mangeat et al, 1999; Martin et al, 1995; Sato et al, 1991, 1992).

Although several authors have speculated that the ERM proteins may play a role in cancer (Tsukita et al, 1994), data concerning their expression in tumors are rather limited (Akisawa et al, 1999; Ichikawa et al, 1998). Interestingly, the neurofibromatosis 2 (NF2) tumor suppressor gene encodes a protein (merlin or schwannomin) structurally related to the ERM family of proteins (Rouleau et al, 1993; Trofatter et al, 1993). Clusters of amino acids identical in merlin and in the ERM family are concentrated in the amino-terminal half of each molecule (about $62 \%$ identical) (Tsukita et al, 1993). Overexpression of the NF2 gene in NIH3T3 cells decreases their growth rate, confirming the role of NF2 as a tumor suppressor (Lutchman and Rou- 
leau, 1995). Merlin is down-regulated in sporadic and NF2-related schwannomas (Stemmer-Rachamimov et al, 1997).

In the present study, we used differential display analysis to identify genes differentially expressed in normal lung versus lung adenocarcinoma. Importantly, we included 10 cases of noninvasive adenocarcinoma (early-stage bronchioloalveolar carcinoma), characterized by in situ growth of tumor cells along the alveolar walls (Kawasaki et al, 1996; Kitamura et al, 1995; Noguchi et al, 1995). These tumors have recently been identified as putative precursors of invasive lung adenocarcinoma (Kawasaki et al, 1996; Kitamura et al, 1995; Noguchi et al, 1995). Analysis of these tumors will allow identification of genes that are either up- or down-regulated in the course of tumor progression. We report here that radixin and, to a lesser extent, moesin are down-regulated both in noninvasive and invasive adenocarcinoma, suggesting that these two molecules may function as tumor suppressors.

\section{Results}

\section{Differential Display Analysis}

Differential display analysis was performed on RNA samples isolated from three noninvasive lung adenocarcinomas (localized bronchioloalveolar carcinomas), two invasive lung adenocarcinomas, and two nontumorous lung tissues. Six downstream primers were used for the reverse transcription of DNase-treated total RNA and the resulting first-strand cDNA was subsequently PCR-amplified using a combination of 17 upstream primers and each of the 6 downstream primers. The differential display using the No 14 upstream primer and the No 5 downstream primer identified a cDNA fragment that was down-regulated in both noninvasive and invasive lung adenocarcinomas. Sequence analysis of the amplified fragment revealed that the cDNA was homologous to human radixin.

\section{Expression of ERM mRNA in Human Lung Adenocarcinomas and Nontumor Lung Tissues}

Next, expression of radixin mRNA was analyzed by real-time quantitative $\mathrm{RT}$-PCR using a panel of total RNA extracted from 10 noninvasive lung adenocarcinomas (early-stage bronchioloalveolar carcinomas), 16 invasive lung adenocarcinomas, and 9 nontumorous lung tissues. As shown in Figure 1, expression of radixin mRNA was decreased in both the 10 earlystage bronchioloalveolar carcinomas and the 16 invasive lung adenocarcinomas by $69 \%(p=0.0002)$ and $82 \%(p<0.0001)$, respectively, as compared with 9 nontumor lung tissues. We also studied expression of moesin and ezrin mRNAs in the same panel of RNA samples. We found that expression of ezrin was down-regulated by $46 \%$ ( $p=0.0033$ ) in noninvasive lung adenocarcinoma and $76 \%(p<0.0001)$ in invasive lung adenocarcinoma. Levels of moesin mRNA were also reduced in lung adenocarcinoma, but to a lesser extent compared with the reduction in radixin
mRNA levels (noninvasive: 44\% reduction, $p=$ 0.0071 ; invasive: $67 \%$ reduction, $p<0.0001$ ).

\section{Immunohistochemical Analysis}

Radixin, moesin, and ezrin were all expressed in normal alveolar and bronchial epithelium, and in vascular endothelial cells (Fig. 2). Weak to moderate staining was observed in the apical or luminal cell membranes. In bronchiolar epithelium the apical portion of the cytoplasm was also stained for radixin and moesin. In contrast most cancer cells were completely negative for radixin or moesin. In general we found no significant heterogeneity of tumor cells with regard to the expression of radixin and moesin. The only heterogeneity was found in a small fraction of cancer cells that were located in the periphery of the tumors; in these cells, we observed weak staining for these two proteins. Unlike radixin or moesin, weak to moderate staining for ezrin was seen in most tumor cells (Fig. 2), except for one tumor, which was negative for ezrin (Fig. 3B). Interestingly, localization of ezrin was altered in a significant proportion of tumor cells: whereas tumor cells forming luminal structures retained membranous staining on the apical side (Fig. 3A), the majority of tumor cells were diffusely stained in the cytoplasm. This was especially evident in tumor cells with disorganized structures (Fig. 3C). In addition we occasionally observed that cancer cells invading the fibrous stroma in a scattered manner were strongly stained for ezrin (Fig. 3, D and E). The results of these immunohistochemical examinations are summarized in Table 1.

\section{Discussion}

In the present study, using differential display analysis, we identified a cDNA fragment that was downregulated in lung adenocarcinoma. Sequence analysis showed that the cDNA was that of radixin, which belongs to the ERM protein family. RT-PCR analysis of a panel of lung adenocarcinoma and nontumor lung tissues showed that radixin was down-regulated in all noninvasive, as well as invasive, adenocarcinomas. Immunohistochemistry further showed that staining for radixin was markedly reduced in tumor cells, whereas non-neoplastic epithelial cells, as well as endothelial cells within the tumor stroma, strongly expressed radixin. Similarly, mRNA levels of moesin and ezrin were reduced in lung adenocarcinomas, although staining intensity for ezrin remained more or less the same as in normal tissue. These results suggest that mRNA expression of radixin and the other ERM proteins is reduced in the early oncogenic stages of lung adenocarcinoma, and that either translational or post-translational control mechanisms may exist for expression of ezrin. Phosphorylation is one of the mechanisms that control the stability of proteins (Ashcroft and Vousden, 1999). Thus it would be interesting to see whether the phosphorylation status of ezrin is altered in lung adenocarcinomas as compared with nontumorous lung tissues. 


\section{A radixin}

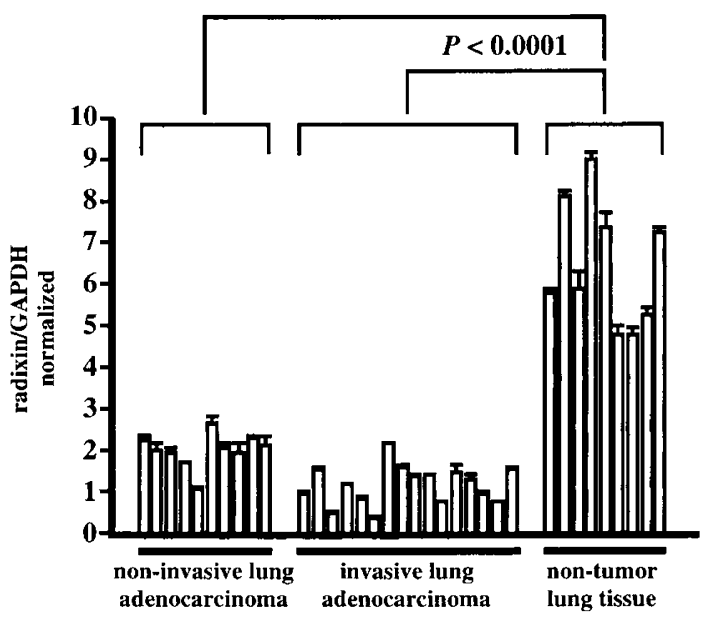

B moesin

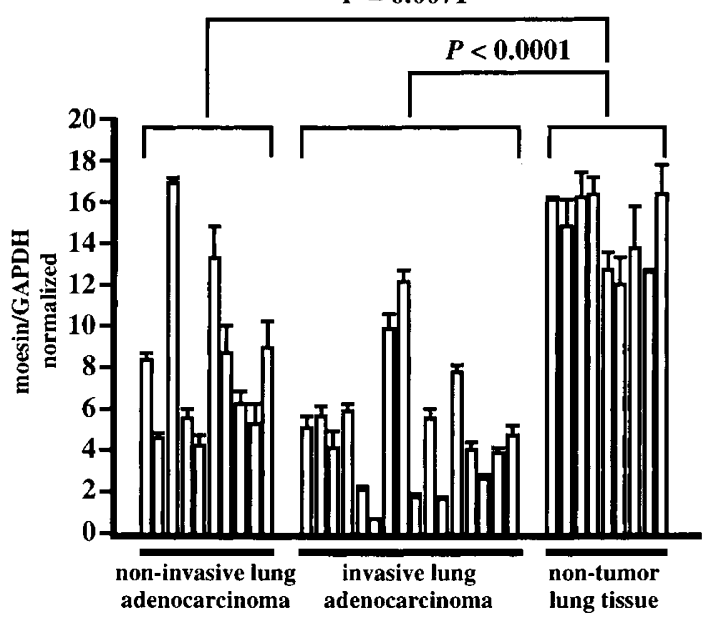

C ezrin

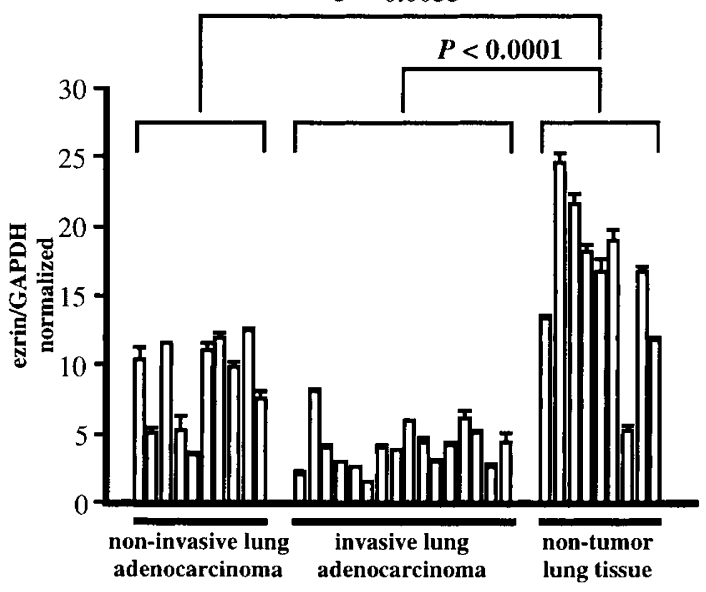

Figure 1.

Real-time quantitative RT-PCR analysis. Expression of the ERM mRNAs was analyzed by real-time quantitative RT-PCR using a panel of total RNA extracted from 10 noninvasive lung adenocarcinomas, 16 invasive lung adenocarcinomas, and 9 nontumor lung tissues. Expression of the ERM mRNAs was decreased in both noninvasive and invasive lung adenocarcinomas compared with nontumor lung tissues. $A$, Expression of radixin mRNA; $B$, expression of ezrin mRNA; $C$, expression of moesin mRNA. Results are the means $\pm \mathrm{SD}$ of three experiments.
Since the ERM proteins are involved in cell migration, the down-regulation of the ERM proteins in lung adenocarcinoma was unexpected. However the following findings point to the possibility that the ERM proteins may function as tumor suppressors. First, the NF2 protein (merlin or schwannomin), which shares structural characteristics with the ERM family, functions as a tumor suppressor (Rouleau et al, 1993; Trofatter et al, 1993). Transfection of the NF2 gene suppressed a v-Ha-Ras-induced malignant phenotype (Tikoo et al, 1994) and inhibited the growth of NIH3T3 cells (Lutchman and Rouleau, 1995). Antisense oligodeoxynucleotides to the NF2 gene inhibited cell adhesion (Huynh and Pulst, 1996). Second, a new growth suppressor gene, designated DAL-1 (differentially expressed in adenocarcinoma of the lung), was recently isolated by differential display analysis. This gene belongs to the NF2/ERM/4.1 superfamily, and its expression is absent in a large proportion of primary non-small-cell lung carcinomas (Tran et al, 1999).

In this respect it is interesting that the radixin gene is localized in 11q23 (Wilgenbus et al, 1993), one of the chromosomal regions commonly showing $\mathrm{LOH}$ in lung adenocarcinoma (lizuka et al, 1995; Rasio et al, 1995). Chromosomal deletions in region 11q23 have been associated with various human tumors including breast (Carter et al, 1994; Hampton et al, 1994; Laake et al, 1999; Negrini et al, 1995; Winqvist et al, 1995), ovarian (Foulkes et al, 1993), uterine cervical (Hampton et al, 1994), and colon (Keldysh et al, 1993) cancer, malignant melanoma (Herbst et al, 1995), and lymphoproliferative disorder (Stilgenbauer et al, 1996). The introduction of normal human chromosome $11 \mathrm{q}$ into the A549 lung adenocarcinoma cell line suppressed tumorigenicity in nude mice (Parshad et al, 1992; Satoh et al, 1993). The tumor suppressive function of $11 \mathrm{q}$ has also been demonstrated in the MCF-7 breast carcinoma cell line (Negrini et al, 1994). Recently regions of allelic loss on chromosome 11q23 in lung cancer have been refined (Wang et al, 1999). The radixin gene is localized to one of the two minimal regions of loss identified ( $\mathrm{Y}$. Arai, Cancer Genomics Division, National Cancer Center Research Institute, Tokyo, Japan, personal communication).

In contrast to radixin and moesin, weak but significant staining for ezrin was observed in the majority of cancer cells. Interestingly, a diffuse cytoplasmic staining pattern was often observed instead of the characteristic membranous staining pattern, especially in areas where tubular structures were disorganized. Moreover ezrin expression appeared to be strongly induced in tumor cells that invaded the stroma in a scattered manner. These observations suggest that ezrin may have a dual role. In cells with polarized structures, ezrin may regulate cell surface morphogenesis as a membrane-cytoskeletal linker (Algrain et al, 1993). In cells responding to extracellular stimuli, such as EGF (Bretscher, 1989) or HGF (Crepaldi et al, 1997), ezrin may be involved in the cytoskeletal reorganization required for migration and morphogenetic changes. In this respect it is of note that alternative 


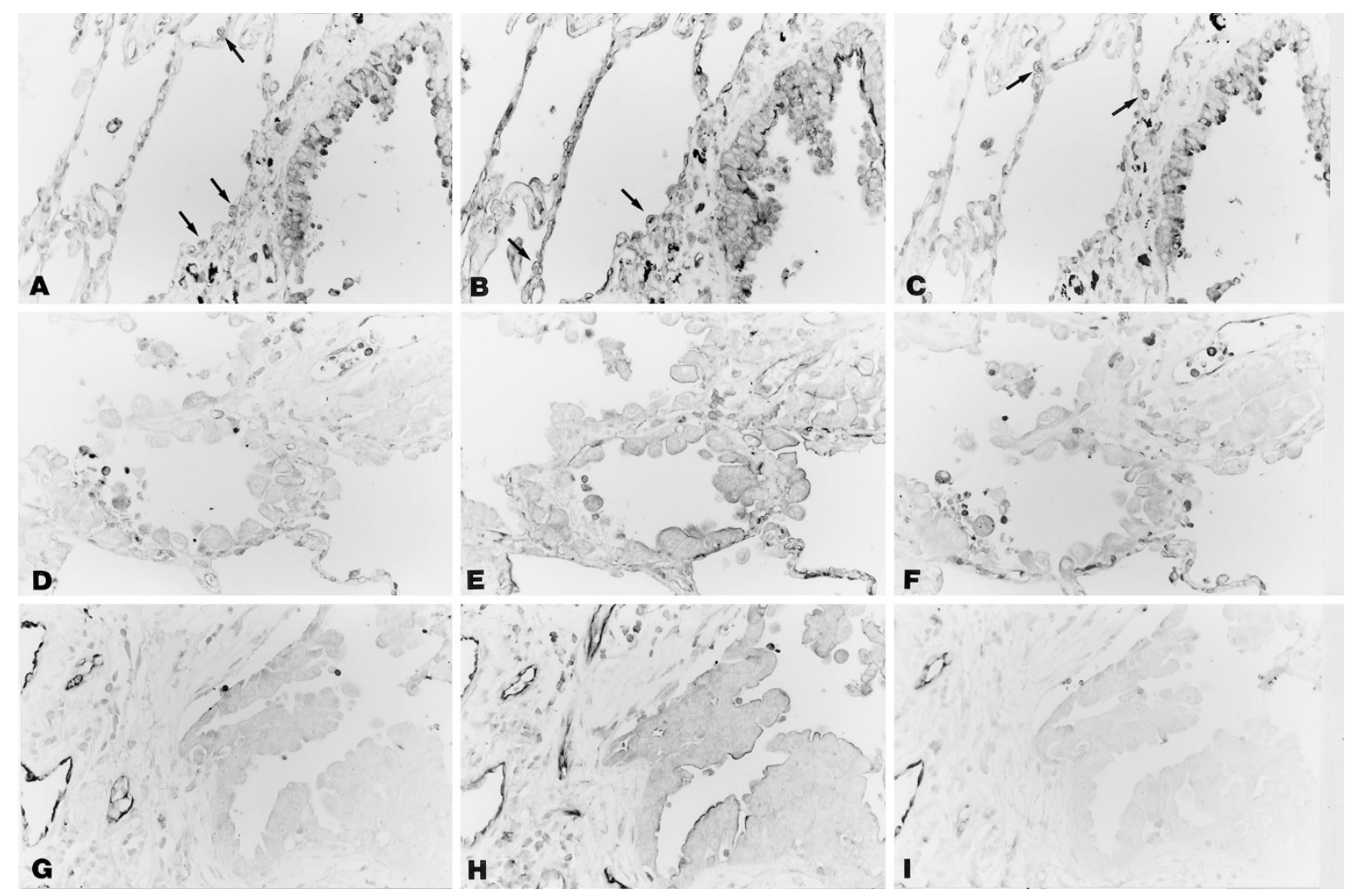

Figure 2.

Immunohistochemistry of the ERM proteins in lung adenocarcinomas. $A$ to $C$, Non-neoplastic bronchiolar and alveolar epithelium. $D$ to $F$, Noninvasive part of the tumor. $G$ to $I$, invasive part of the tumor. $A, D$, and $G$, Radixin; $B, E$, and $H$, ezrin; $C, F$, and $I$, moesin. Radixin, moesin, and ezrin were all expressed in normal alveolar (arrows) and bronchial epithelium ( $A$ to $C$ ), and in vascular endothelial cells. Weak to moderate staining was observed in the apical or luminal cell membranes. $A$ fraction of tumor cells in the peripheral noninvasive part of the tumor occasionally stained weakly positive for radixin and moesin, but staining intensity was reduced compared with non-neoplastic bronchiolar epithelium $(D$ and $F$ ). Overall, the majority of cancer cells were negative for radixin and moesin ( $G$ and $I$ ). In contrast to radixin and ezrin, weak immunoreactivity for ezrin was detected in most cancer cells $(E$ and $H)$. $A$ to $I$, original magnification, $\times 100$.

splicing and expression levels of CD44, an ERMbinding membrane protein, correlate with tumor progression (Rudzki and Jothy, 1997). It would be interesting to see whether the loss of membrane association of ezrin occurs in parallel with the loss of ezrin binding by CD44 and/or altered expression pattern of CD44 isoforms, and whether phosphorylation of ezrin plays a role in this process. Clearly further investigations are required to elucidate the potential roles of ezrin in cancer cell invasion.

In summary we have found that radixin and moesin are down-regulated in lung adenocarcinoma, including early-stage bronchioloalveolar carcinoma, suggesting that these two molecules may function as tumor suppressors in the early oncogenic stages of lung adenocarcinoma. Expression of ezrin was also reduced in lung adenocarcinoma, but its altered localization in invading cancer cells points to its role in cell migration. The precise roles of the ERM proteins in cancer cells should be elucidated by further investigations.

\section{Materials and Methods}

\section{Patients and Samples}

Tumor samples were obtained from 26 patients, of whom 10 had noninvasive and 16 had invasive lung adenocarcinomas. All patients underwent complete resection of the tumors at the National Cancer Center Hospital, Japan. After surgical removal, samples of the tissues were stored in liquid nitrogen until they were used. The remaining tissues were fixed routinely in $10 \%$ formalin and embedded in paraffin for pathological examination.

\section{RNA Isolation}

Total RNA was isolated from frozen tissue using a RNeasy Mini Kit (Qiagen, Valencia, California). All RNA samples were treated with deoxyribonuclease I (Amplification Grade; Life Technologies, Rockville, Maryland), following the instructions of the manufacturer.

\section{Differential Display Analysis}

We carried out differential display analysis following a modified protocol described by Yoshikawa et al (1998). Experiments were performed using a Fluorescence Differential Display Kit Rhodamine version (Code No.DS003; TaKaRa, Tokyo, Japan). Total RNA (250 ng) was combined with a ROX (carboxy-Xrhodamine) labeled downstream primer, 10× RNA PCR buffer, $25 \mathrm{~mm} \mathrm{MgCl}_{2}$, dNTP mixture, RNase inhibitor, AMV Reverse Transcriptase XL, and RNase free $\mathrm{dH}_{2} \mathrm{O}$. The reaction mixture was incubated at 


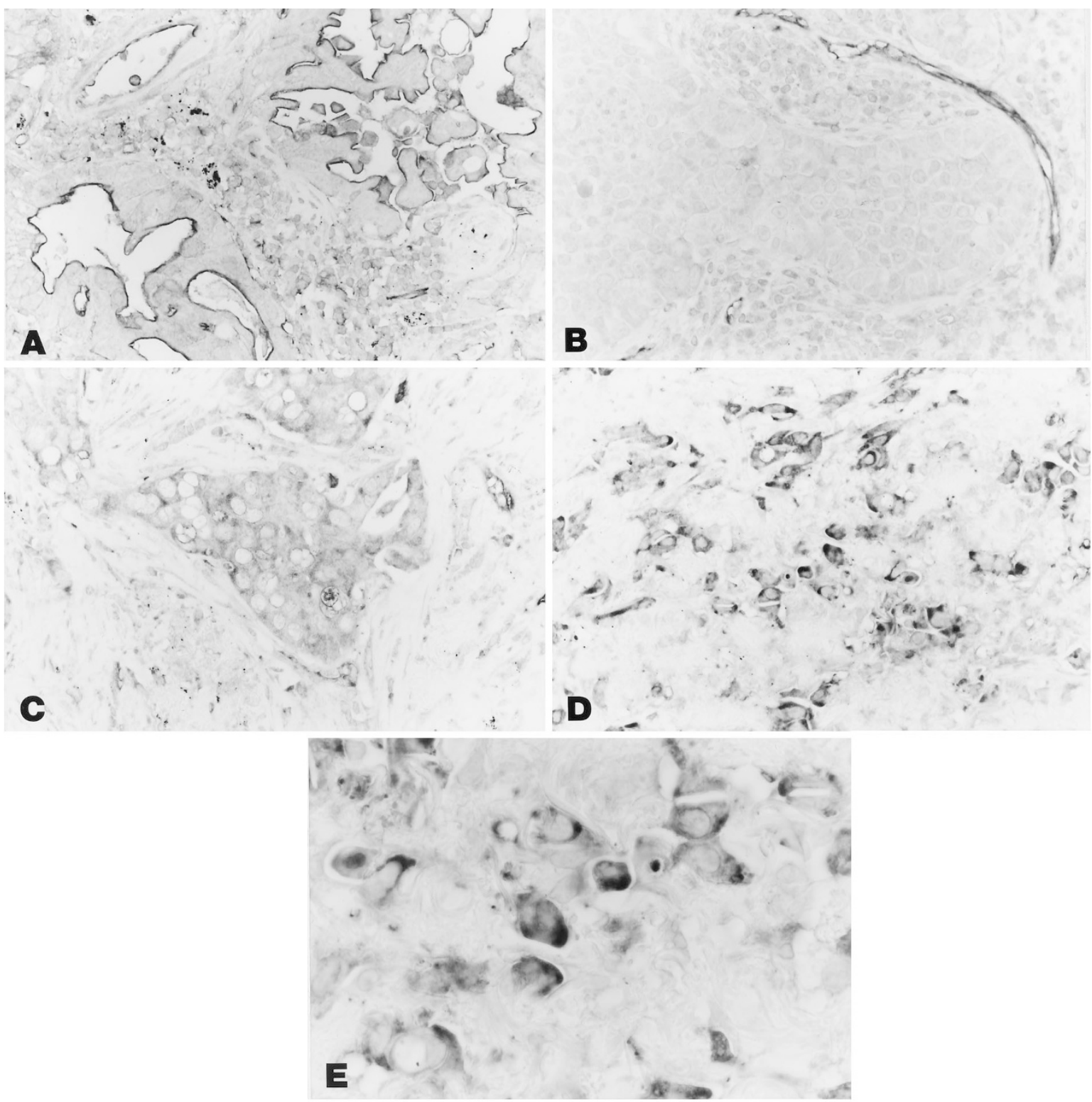

Figure 3.

Immunohistochemistry of the ezrin protein in lung adenocarcinoma. Unlike radixin or moesin, weak to moderate staining for ezrin was seen in most tumor cells $(A$ $C$, and $D$ ), except for one tumor which was completely negative $(B)$. Localization of ezrin was altered in a significant proportion of tumor cells. Whereas tumor cells forming luminal structures retained membranous staining on the apical side $(A)$, the majority of tumor cells were diffusely stained in the cytoplasm $(C)$. This was especially evident in tumor cells with disorganized structures. In addition, cancer cells invading the fibrous stroma in a scattered manner were strongly stained for ezrin $(D)$. $A$ to $D$, Original magnification, $\times 100 ; E$, higher magnification of $D$ (original magnification, $\times 250$ ).

$55^{\circ} \mathrm{C}$ for 30 minutes, $95^{\circ} \mathrm{C}$ for 5 minutes, and $5^{\circ} \mathrm{C}$ for 5 minutes for one cycle. PCR amplification of the generated cDNA fragments was done by adding $10 \times$ LA PCR Buffer II, $25 \mathrm{~mm} \mathrm{MgCl}_{2}$, optimized concentrations of dNTP mixture, TAKARA LA Taq, $\mathrm{dH}_{2} \mathrm{O}$, first cDNA fragments, a ROX-labeled downstream primer, and random 10-mer oligonucleotides-added poly (A)+ upstream primer (TaKaRa). Amplification was performed at $94^{\circ} \mathrm{C}$ for 2 minutes, $40^{\circ} \mathrm{C}$ for 5 minutes, and $72^{\circ} \mathrm{C}$ for 5 minutes for one cycle, at $94^{\circ} \mathrm{C}$ for 30 seconds, $40^{\circ} \mathrm{C}$ for 2 minutes, and $72^{\circ} \mathrm{C}$ for 1 minute for 34 cycles, and at $72^{\circ} \mathrm{C}$ for 5 minutes for one cycle. Products were separated in a $6 \%$ polyacrylamide-urea gel. The fluorescence-amplified fragments were visu- alized by FMBIOII Multi-View (Code HT200; TaKaRa). Fragments determined to be differentially expressed were eluted by cutting out a piece of gel containing the band, placing it in an Eppendorf tube containing $50 \mu \mathrm{l}$ of distilled water, and then incubating the gel at room temperature for 30 minutes and at $100^{\circ} \mathrm{C}$ for 10 minutes. A second PCR amplification of the fragments was performed by adding 10× LA PCR Buffer II, 25 $\mathrm{mM} \mathrm{MgCl}_{2}$ optimized concentrations of dNTP mixture, TAKARA LA Taq, $\mathrm{dH}_{2} \mathrm{O}$, second cDNA fragments, a ROX-labeled downstream primer, and random 10-mer oligonucleotides-added poly $(A)+$ upstream primer (TaKaRa). Amplification was performed at $94^{\circ} \mathrm{C}$ for 2 minutes for one cycle, and $94^{\circ} \mathrm{C}$ for 30 seconds, 
Table 1. Results of Immunohistochemical Examinations ${ }^{a}$

\begin{tabular}{|c|c|c|c|c|}
\hline & Radixin & Ezrin & \multicolumn{2}{|c|}{ Moesin } \\
\hline \multicolumn{5}{|c|}{ Noninvasive lung adenocarcinoma } \\
\hline++ & $(0 \%)$ & $(0 \%)$ & $0 / 10$ & $(0 \%)$ \\
\hline+ & $(30 \%)$ & $10 / 10 \quad(100 \%)$ & $1 / 10$ & $(10 \%)$ \\
\hline- & $(70 \%)$ & $0 / 10 \quad(0 \%)$ & $9 / 10$ & $(90 \%)$ \\
\hline \multicolumn{5}{|c|}{ Invasive lung adenocarcinoma } \\
\hline++ & $(0 \%)$ & $(0 \%)$ & $0 / 16$ & $(0 \%)$ \\
\hline+ & $(0 \%)$ & $(94 \%)$ & $0 / 16$ & $(0 \%)$ \\
\hline- & $16 / 16 \quad(100 \%)$ & $(6 \%)$ & $16 / 16$ & $(100 \%)$ \\
\hline
\end{tabular}

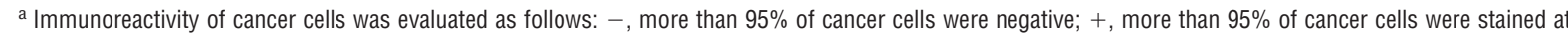
about the same intensity as non-neoplastic epithelial cells; ++ , more than $95 \%$ of cancer cells were stained more intensely than non-neoplastic epithelial cells. In general, no significant heterogeneity of tumor cells was observed with regard to the staining for the ERM (ezrin/radixin/moesin) proteins.

$40^{\circ} \mathrm{C}$ for 2 minutes, and $72^{\circ} \mathrm{C}$ for 1 minute for 21 cycles. The amplified fragments were separated with 2\% NuSieve 3:1 agarose gel containing HA Yellow (TaKaRa) and 2\% NuSieve 3:1 agarose gel containing HA Red (TaKaRa).

The fragments were sequenced using a Big Dye Cycle Sequencing FS Ready Reaction Kit (Applied Biosystems/Perkin Elmer, Foster City, California) in an ABI PRISM 377 Automated DNA sequencer (Applied Biosystems/Perkin Elmer). The DNA sequences were evaluated by FASTA and BLAST computer programs at the National Center for Biotechnology Information.

\section{Primers}

Primers for radixin, moesin, and ezrin were designed using a computer program, Primer Express (Applied Biosystems/Perkin Elmer). We conducted BLASTN searches against $\mathrm{nr}$ (the nonredundant set of GenBank, EMBL, and DDBJ database sequences) to confirm the total gene specificity of the nucleotide sequences chosen for the primers. The primers used for real-time quantitative $R T-P C R$ were: radixin, forward 5'-CGAGGAAGAACGTGTAACCGAA-3' and reverse 5'-TCTTGGTTTCATCTCTGGCTTG-3'; moesin, forward 5'-TGTAAACCAGAGAGCTGCTGG-3' and reverse 5'-GAAGAGCACACATGAGACAGAGAA-3'; and ezrin, forward 5'-GTTTTCCCCAGTTGTAATAGT GCC-3' and reverse 5'-TCCGTAATTCAATCAG TCCTGC-3'. These primers were purchased from Greiner Japan (Tokyo). GAPDH primers were purchased from Perkin-Elmer Applied Biosystems.

\section{Real-Time Quantitative RT-PCR Analysis}

We carried out a real-time quantitative RT-PCR assay (Gibson et al, 1996; Heid et al, 1996) based on SYBR Green fluorescence methodology to determine the relative abundance of radixin, moesin, and ezrin $\mathrm{mR}$ NAs. All RT-PCR reactions were performed using an ABI Prism 7700 Sequence Detector (Applied Biosystems/Perkin Elmer). For each RT-PCR run, a master mix was prepared on ice with $10 \times$ SYBR PCR Buffer, $25 \mathrm{~mm} \mathrm{MgCl}_{2}$, dNTP blend, AmpliTaq Gold, MultiScribe Reverse Transcriptase, RNase inhibitor, $\mathrm{dH}_{2} \mathrm{O}$ (Applied Biosystems/Perkin Elmer). One microliter of the RNA samples was added to $49 \mu$ l of the RT-PCR master mix. The thermal cycling conditions consisted of an initial denaturation step at $48^{\circ} \mathrm{C}$ for 30 minutes, $95^{\circ} \mathrm{C}$ for 10 minutes, 40 cycles at $95^{\circ} \mathrm{C}$ for 15 seconds, and $60^{\circ} \mathrm{C}$ for 1 minute. Experiments were performed in triplicate for each data point. Each RTPCR run included the five points of the standard curve (5-fold serially diluted human control RNAs), a notemplate control, and 35 RNA samples derived from 16 invasive lung adenocarcinomas, 10 small (maximum diameter $2 \mathrm{~cm}$ or less) bronchioloalveolar carcinomas, and 9 normal lung tissues. We quantified transcripts of the GAPDH as internal RNA controls, and each sample was normalized on the basis of its GAPDH content.

\section{Immunohistochemical Analysis}

The tissue specimens were fixed in $10 \%$ formalin, embedded in paraffin, and sliced into $3-\mu \mathrm{m}$ sections. Immunoperoxidase staining by the avidin-biotinperoxidase complex method was performed with a Vectastain ABC kit (Vector Laboratories, Burlingame, California). The sections were deparaffinized with graded ethanol and xylene, immersed for 30 minutes in methanol containing $0.3 \% \mathrm{H}_{2} \mathrm{O}_{2}$, and washed in phosphate-buffered saline ( $\mathrm{pH}$ 7.4). After autoclaving, the sections were incubated for 10 minutes with normal swine serum to block nonspecific binding of the antibody. The sections were exposed to polyclonal goat anti-radixin antibody (sc-6408, Santa Cruz Biotechnology) at a dilution of 1:2000, polyclonal goat anti-ezrin antibody (sc-6409, Santa Cruz Biotechnology, Santa Cruz, California) at a dilution of 1:200, or polyclonal goat anti-moesin antibody (sc-6410, Santa Cruz Biotechnology) at a dilution of $1: 2000$, at $4^{\circ} \mathrm{C}$ overnight. The sections were then incubated with biotinylated secondary antibody for 30 minutes at room temperature, and with the Vectastain $A B C$ reagent for 30 minutes. For visualization, sections were immersed in $0.05 \%$ diaminobenzidine tetrahydrochloride solution containing $0.01 \% \mathrm{H}_{2} \mathrm{O}_{2}$, and counterstained lightly with hematoxylin.

\section{Statistical Analysis}

The difference between groups was first analyzed by the Kruskal-Wallis test. If a statistically significant 
difference was observed, the difference between the two groups was analyzed by the Mann-Whitney $U$ test. Calculations were performed using the computer program StatView (Abacus Concepts, Berkeley, California). The difference was considered significant if the $p$ value was less than 0.05 .

\section{Acknowledgements}

We thank Dr. Y. Arai, Cancer Genomics Division, National Cancer Center Research Institute, Tokyo, Japan, for providing us with the unpublished data on the radixin gene. We thank Mrs. Y. Yamauchi for technical assistance.

\section{References}

Akisawa N, Nishimori I, Iwamura T, Onishi S, and Hollingsworth MA (1999). High levels of ezrin expressed by human pancreatic adenocarcinoma cell lines with high metastatic potential. Biochem Biophys Res Commun 258:395-400.

Algrain M, Turunen O, Vaheri A, Louvard D, and Arpin M (1993). Ezrin contains cytoskeleton and membrane binding domains accounting for its proposed role as a membranecytoskeletal linker. J Cell Biol 120:129-139.

Ashcroft M and Vousden KH (1999). Regulation of p53 stability. Oncogene 18:7637-7643.

Bauer D, Muller H, Reich J, Riedel H, Ahrenkiel V, Warthoe P, and Strauss M (1993). Identification of differentially expressed mRNA species by an improved display technique (DDRT-PCR). Nucleic Acids Res 21:4272-4280.

Bretscher A (1989). Rapid phosphorylation and reorganization of ezrin and spectrin accompany morphological changes induced in A-431 cells by epidermal growth factor. J Cell Biol 108:921-930.

Bretscher A, Reczek D, and Berryman M (1997). Ezrin: A protein requiring conformational activation to link microfilaments to the plasma membrane in the assembly of cell surface structures. J Cell Sci 110:3011-3018.

Carter SL, Negrini M, Baffa R, Gillum DR, Rosenberg AL, Schwartz GF, and Croce CM (1994). Loss of heterozygosity at 11q22-q23 in breast cancer. Cancer Res 54:6270-6274.

Crepaldi T, Gautreau A, Comoglio PM, Louvard D, and Arpin $M$ (1997). Ezrin is an effector of hepatocyte growth factormediated migration and morphogenesis in epithelial cells. J Cell Biol 138:423-434.

Foulkes WD, Campbell IG, Stamp GW, and Trowsdale J (1993). Loss of heterozygosity and amplification on chromosome 11q in human ovarian cancer. Br J Cancer 67:268-273.

Gibson UE, Heid CA, and Williams PM (1996). A novel method for real time quantitative RT-PCR. Genome Res 6:995-1001.

Hampton GM, Mannermaa A, Winquist R, Alavaikko M, Blanco G, Taskinen PJ, Kiviniemi H, Newsham I, Cavenee WK, and Evans GA (1994). Loss of heterozygosity in sporadic human breast carcinoma: A common region between 11q22 and 11q23.3. Cancer Res 54:4586-4589.

Hampton GM, Penny LA, Baergen RN, Larson A, Brewer C, Liao S, Busby-Earle RM, Williams AW, Steel CM, Bird CC, Stanbridge EJ, and Evans GA (1994). Loss of heterozygosity in cervical carcinoma: Subchromosomal localization of a putative tumor suppressor gene to chromosome 11q22-q24. Proc Natl Acad Sci USA 91:6953-6957.

Heid CA, Stevens J, Livak KJ, and Williams PM (1996). Real time quantitative PCR. Genome Res 6:986-994.

Heiska L, Alfthan K, Gronholm M, Vilja P, Vaheri A, and Carpen O (1998). Association of ezrin with intercellular adhesion molecule-1 and -2 (ICAM-1 and ICAM-2): Regulation by phosphatidylinositol 4:5-bisphosphate. J Biol Chem 273:21893-21900.

Henry MD, Gonzalez Agosti C, and Solomon F (1995). Molecular dissection of radixin: distinct and interdependent functions of the amino- and carboxy-terminal domains. J Cell Biol 129:1007-1022.

Herbst RA, Larson A, Weiss J, Cavenee WK, Hampton GM, and Arden KC (1995). A defined region of loss of heterozygosity at 11q23 in cutaneous malignant melanoma. Cancer Res 55:2494-2496.

Huynh DP and Pulst SM (1996). Neurofibromatosis 2 antisense oligodeoxynucleotides induce reversible inhibition of schwannomin synthesis and cell adhesion in STS26T and T98G cells. Oncogene 13:73-84.

Ichikawa T, Masumoto J, Kaneko M, Saida T, Sagara J, and Taniguchi S (1998). Moesin and CD44 expression in cutaneous melanocytic tumours. $\mathrm{Br} J$ Dermatol 138:763-768.

lizuka $M$, Sugiyama $Y$, Shiraishi $M$, Jones $C$, and Sekiya $T$ (1995). Allelic losses in human chromosome 11 in lung cancers. Genes Chromosomes Cancer 13:40-46.

Kawasaki M, Noguchi M, Morikawa A, Matsuno Y, Yamada T, Hirohashi S, Kondo H, and Shimosato Y (1996). Nuclear p53 accumulation by small-sized adenocarcinomas of the lung. Pathol Int 46:486-490.

Keldysh PL, Dragani TA, Fleischman EW, Konstantinova LN, Perevoschikov AG, Pierotti MA, Della Porta G, and Kopnin BP (1993). 11q deletions in human colorectal carcinomas: Cytogenetics and restriction fragment length polymorphism analysis. Genes Chromosomes Cancer 6:45-50.

Kitamura H, Kameda Y, Nakamura N, Nakatani Y, Inayama $\mathrm{Y}$, lida M, Noda K, Ogawa N, Shibagaki T, and Kanisawa M (1995). Proliferative potential and p53 overexpression in precursor and early-stage lesions of bronchioloalveolar lung carcinoma. Am J Pathol 146:876-887.

Laake K, Launonen V, Niederacher D, Gudlaugsdottir S, Seitz S, Rio P, Champeme MH, Bieche I, Birnbaum D, White G, Sztan M, Sever N, Plummer S, Osorio A, Broeks A, Huusko P, Spurr N, Borg A, Cleton Jansen AM, van't Veer L, Benitez J, Casey G, Peterlin B, Olah E, Borresen-Dale A-L, and the Breast Cancer Somatic Genetics Consortium (1999). Loss of heterozygosity at 11q23.1 and survival in breast cancer: Results of a large European study. Genes Chromosomes Cancer 25:212-221.

Lankes WT and Furthmayr H (1991). Moesin: A member of the protein 4.1-talin-ezrin family of proteins. Proc Natl Acad Sci USA 88:8297-8301.

Liang P, Averboukh L, Keyomarsi K, Sager R, and Pardee AB (1992). Differential display and cloning of messenger RNAs from human breast cancer versus mammary epithelial cells. Cancer Res 52:6966-6968.

Liang P, Averboukh L, and Pardee AB (1993). Distribution and cloning of eukaryotic mRNAs by means of differential display: Refinements and optimization. Nucleic Acids Res 21:3269-3275. 
Liang P and Pardee AB (1992). Differential display of eukaryotic messenger RNA by means of the polymerase chain reaction [see comments]. Science 257:967-971.

Lutchman M and Rouleau GA (1995). The neurofibromatosis type 2 gene product, schwannomin, suppresses growth of NIH 3T3 cells. Cancer Res 55:2270-2274.

Mangeat P, Roy C, and Martin M (1999). ERM proteins in cell adhesion and membrane dynamics. Trends Cell Biol 9:187-192.

Martin M, Andreoli C, Sahuquet A, Montcourrier P, Algrain M, and Mangeat $\mathrm{P}$ (1995). Ezrin NH2-terminal domain inhibits the cell extension activity of the $\mathrm{COOH}$-terminal domain. J Cell Biol 128:1081-1093.

Negrini M, Rasio D, Hampton GM, Sabbioni S, Rattan S, Carter SL, Rosenberg AL, Schwartz GF, Shiloh Y, Cavenee WK, and Croce CM (1995). Definition and refinement of chromosome 11 regions of loss of heterozygosity in breast cancer: Identification of a new region at 11q23.3. Cancer Res 55:3003-3007.

Negrini M, Sabbioni S, Possati L, Rattan S, Corallini A, Barbanti-Brodano G, and Croce CM (1994). Suppression of tumorigenicity of breast cancer cells by microcell-mediated chromosome transfer: Studies on chromosomes 6 and 11. Cancer Res 54:1331-1336.

Noguchi M, Morikawa A, Kawasaki M, Matsuno Y, Yamada T, Hirohashi S, Kondo H, and Shimosato Y (1995). Small adenocarcinoma of the lung: Histologic characteristics and prognosis. Cancer 75:2844-2852.

Parshad R, Price FM, Oshimura M, Barrett JC, Satoh H, Weissman BE, Stanbridge EJ, and Sanford KK (1992). Complementation of a DNA repair deficiency in six human tumor cell lines by chromosome 11. Hum Genet 88:524-528.

Rasio D, Negrini M, Manenti G, Dragani TA, and Croce CM (1995). Loss of heterozygosity at chromosome 11q in lung adenocarcinoma: Identification of three independent regions. Cancer Res 55:3988-3991.

Rouleau GA, Merel P, Lutchman M, Sanson M, Zucman J, Marineau C, Hoang-Xuan K, Demczuk S, Desmaze C, Plougastel B, Pulst SM, Lenoir G, Bijlsma E, Fashold R, Dumanski J, de Jong $P$, Parry $D$, Eldrige $R$, Aurias $A$, Delattre O, and Thomas G (1993). Alteration in a new gene encoding a putative membrane-organizing protein causes neuro-fibromatosis type 2 [see comments]. Nature 363: 515-521.

Rudzki Z and Jothy S (1997). CD44 and the adhesion of neoplastic cells. Mol Pathol 50:57-71.

Sager R, Anisowicz A, Neveu M, Liang P, and Sotiropoulou G (1993). Identification by differential display of alpha 6 integrin as a candidate tumor suppressor gene. FASEB J 7:964-970.

Sato N, Funayama N, Nagafuchi A, Yonemura S, and Tsukita $S$ (1992). A gene family consisting of ezrin, radixin and moesin: Its specific localization at actin filament/plasma membrane association sites. J Cell Sci 103:131-143.

Sato N, Yonemura S, Obinata T, and Tsukita S (1991). Radixin, a barbed end-capping actin-modulating protein, is concentrated at the cleavage furrow during cytokinesis [published erratum appears in J Cell Biol 114:1101-1103]. J Cell Biol 113:321-330.

Satoh H, Lamb PW, Dong JT, Everitt J, Boreiko C, Oshimura M, and Barrett JC (1993). Suppression of tumorigenicity of A549 lung adenocarcinoma cells by human chromosomes 3 and 11 introduced via microcell-mediated chromosome transfer. Mol Carcinog 7:157-164.
Stemmer-Rachamimov AO, Xu L, Gonzalez-Agosti C, Burwick JA, Pinney D, Beauchamp R, Jacoby LB, Gusella JF, Ramesh V, and Louis DN (1997). Universal absence of merlin, but not other ERM family members, in schwannomas. Am J Pathol 151:1649-1654.

Stilgenbauer S, Liebisch P, James MR, Schroder M, Schlegelberger B, Fischer K, Bentz M, Lichter P, and Dohner H (1996). Molecular cytogenetic delineation of a novel critical genomic region in chromosome bands 11q22.3-923.1 in lymphoproliferative disorders [published erratum appears in Proc Natl Acad Sci USA 93:14992]. Proc Natl Acad Sci USA 93:11837-11841.

Tikoo A, Varga M, Ramesh V, Gusella J, and Maruta H (1994). An anti-Ras function of neurofibromatosis type 2 gene product (NF2/Merlin). J Biol Chem 269:23387-23390.

Tran YK, Bogler O, Gorse KM, Wieland I, Green MR, and Newsham IF (1999). A novel member of the NF2/ERM/4.1 superfamily with growth suppressing properties in lung cancer. Cancer Res 59:35-43.

Trofatter JA, MacCollin MM, Rutter JL, Murrell JR, Duyao MP, Parry DM, Eldridge R, Kley N, Menon AG, Pulaski K, Haase VH, Ambrose CM, Munroe D, Bove C, Haines JL, Martuza RL, MacDonald ME, Seizinger BR, Short MP, Buckler AJ, and Gusella JF (1993). A novel moesin, ezrin-, radixin-like gene is a candidate for the neurofibromatosis 2 tumor suppressor [published erratum appears in Cell 75:826]. Cell 72:791-800.

Tsukita S and Hieda $Y$ (1989). A new 82-kD barbed endcapping protein (radixin) localized in the cell-to-cell adherens junction: Purification and characterization. J Cell Biol 108: 2369-2382.

Tsukita S, Itoh, M, Nagafuchi A, and Yonemura S (1993). Submembranous junctional plaque proteins include potential tumor suppressor molecules. J Cell Biol 123:1049-1053.

Tsukita S, Nagafuchi A, and Yonemura S (1994). Possible involvement of adherens junction plaque proteins in tumorigenesis and metastasis. Princess Takamatsu Symp 24:38-50.

Turunen O, Wahlstrom T, and Vaheri A (1994). Ezrin has a $\mathrm{COOH}$-terminal actin-binding site that is conserved in the ezrin protein family. J Cell Biol 126:1445-1453.

Wang SS, Virmani A, Gazdar AF, Minna JD, and Evans GA (1999). Refined mapping of two regions of loss of heterozygosity on chromosome band 11q23 in lung cancer. Genes Chromosomes Cancer 25:154-159.

Wilgenbus KK, Milatovich A, Francke $\mathrm{U}$, and Furthmayr $\mathrm{H}$ (1993). Molecular cloning, cDNA sequence, and chromosomal assignment of the human radixin gene and two dispersed pseudogenes. Genomics 16:199-206.

Winqvist R, Hampton GM, Mannermaa A, Blanco G, Alavaikko M, Kiviniemi $H$, Taskinen PJ, Evans GA, Wright FA, Newsham I, and Cavenee WK (1995). Loss of heterozygosity for chromosome 11 in primary human breast tumors is associated with poor survival after metastasis. Cancer Res 55:2660-2664.

Yonemura S, Hirao M, Doi Y, Takahashi N, Kondo T, and Tsukita S (1998). Ezrin/radixin/moesin (ERM) proteins bind to a positively charged amino acid cluster in the juxtamembrane cytoplasmic domain of CD44, CD43, and ICAM-2. J Cell Biol 140:885-895.

Yoshikawa Y, Mukai H, Asada K, Hino F, and Kato I (1998). Differential display with carboxy-X-rhodamine-labeled primers and the selection of differentially amplified cDNA fragments without cloning. Anal Biochem 256:82-91. 